図より明らかなように, 同一比重の骨材を得る焼結温度はかな り広範用に亘つているが, 各炭鉱試料の灰の成分組成が異なるた めと考えられる。しかしながらいずれの試料も焼結温度の上昇と ともに絶乾比重が低下しており，人工軽量骨材となり得るものと 考えられるが, 焼結温度の高いものについては焼結温度を低下さ せる添加物を, またFlux 成分が多く炉内で融着塊の発生するお それのあるものについては, $\mathrm{SiO}_{2} や \mathrm{Al}_{2} \mathrm{O}_{3}$ の成分が多い粘土等 をバインダとして使用するなどを炭鉱別に検討する必要がある。

$$
\text { 4. ロータリーキルンによる焼結試験 }
$$

キルン内径 $600 \mathrm{~mm}$ 長さ $7 \mathrm{~m}$ のロータリーキルンを使用し, 赤 平フィルタブレスケーキの燃焼 (萑原製作所の横型流動燃焼炉) による脱炭灰に $0.5 \%$ の PVAを加えて造粒乾燥したペレットを原 料とし,プロパンガスを熱源とする焼結温度 $1,200 \sim 1,240^{\circ} \mathrm{C} ・$ キ ルン回転数 $1 \sim 2$ 回 $/ \mathrm{min}$ ・キルン傾斜 $0.5 \sim 1$ 度. 原料のキルン内 滞留時間 $40 \sim 70$ 分・ペレット供給量 $5 \sim 70 \mathrm{~kg} / \mathrm{h}$ の条件で焼結試 験を行なつた。

焼結骨材の比重は, 焼結温度 $1,240^{\circ} \mathrm{C}$. 滞留時間 40 分で約 1.2 の ものが, また焼結温度 $1,210^{\circ} \mathrm{C} \cdot$ 滞留時間 70 分で $1.2 \sim 1.4$ のもの が得られており, 焼結温度と滞留時間のバランスにより目標比重 の骨材が得られる。

ロータリーキルンで焼結する場合の最大難関は, キルン内でペ レットとペレット・ペレットと炉壁の融着が起こり, 融着塊が発 生して運転不能となることである。当所では珪砂を混入して融着 塊の発生を防止し得た。珪砂の粒度は 4 号（1.5〜0.5 mm 95\%， $0.5 \mathrm{~mm}$ 以下 $5 \%$ ) および 5 号 ( $1 \sim 0.5 \mathrm{~mm} 45 \%, 0.5 \mathrm{~mm}$ 以下 55 \%) で試験を行なつたが， 5 号は $0.5 \mathrm{~mm}$ 以下が多いため気流に よる排気中への損失が大きく，4号が適当と考えられる。珠砂の 必要混入量は, ペレット供給量の $60 \sim 100 \%$ 程度と考えているが, 53 年度に必要混入最低量のは把をする予定である。また珠砂は 全量が骨材に付着して排出されるわけではなく, 大部分は単体で 排出され, 付着して損失となる量は骨材の $0.7 \%$ 程度で, 他は回 収して循環使用できる。

\section{5. 製造コストの試算}

立地条件を北海道中央部と仮定，原料は然焼による脱炭灰とし， 焼結には $\mathrm{C}$ 重油を, 脱じんには電気集じん機を, 排煙脱硫の吸収 剂には $\mathrm{Ca}(\mathrm{OH})_{2}$ （消石灰）を使用する等の条件で, 生産規模 5 万 $\mathrm{m}^{3}$ 年・ 10 万 $\mathrm{m}^{3}$ 年・ 20 万 $\mathrm{m}^{3}$ 年の 3 種につき,工場建設費お よび製造コストの試算を行ないその結果を第 7 表および第 8 表に 示す。

1 万 $\mathrm{m}^{3}$ 当りの建設費は, 生産規模 $5 \mathrm{j} \mathrm{m}^{3} /$ 年で 165,800 千円, 10 万 $\mathrm{m}^{3} /$ 年で 113,710 千円, 20 万 $\mathrm{m}^{3} /$ 年で 84,500 千円,と規模の 増大とともに割安となる。

粗骨材の販売価格は, 東京近郊着値で 8,000 円 $/ \mathrm{m}^{3}$ 程度であり, 生産規模 20 万 $\mathrm{m}^{3} /$ 年の場合のコスト 6,211 円 $/ \mathrm{m}^{3}$ は採算圏に入る ように考えられるが, 第 8 表のコスト試算では, 需要地までの運 賃および販売経費が含まれていないこと, 需要地が関東・関西が
第 7 表 人工軽量骨材製造工場建設費試算表

\begin{tabular}{|c|c|c|c|}
\hline 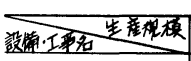 & $5 \delta m^{3} / 4$ & $105 \mathrm{~m}^{2} / 4$ & $20 \mathrm{Jm}^{2} / 4$ \\
\hline 栈械放牌贵 & 370,900 & 559,200 & 878.500 \\
\hline 配管杖料 & & 56,000 & 88,000 \\
\hline 据付配管工事 & 48.000 & 72.700 & 102.100 \\
\hline 電总工事 & & 000 & 124.800 \\
\hline 埻装工事 & & 39.600 & 44,000 \\
\hline 保温工束 & & 11,000 & 19,000 \\
\hline 架台工事 & & 10.400 & 13,000 \\
\hline 基哝工事 & 81,200 & 111,500 & 186,900 \\
\hline 建家工事 & 133,400 & 148,300 & 212.900 \\
\hline 塗装工事 & & & 5,900 \\
\hline 荷造鋉送 & & 9,500 & 12.000 \\
\hline 試遈転王会 & 3,000 & 3,000 & 3,000 \\
\hline 全: 訆 & 829,000 & 1.137 .100 & $1.690,100$ \\
\hline
\end{tabular}

第 8 表人工軽量骨材製造コスト試算表

\begin{tabular}{|c|c|c|c|c|c|c|c|}
\hline \multirow{2}{*}{\multicolumn{2}{|c|}{ 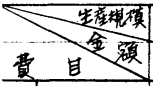 }} & \multicolumn{2}{|c|}{$5 \delta \mathrm{m}^{3} /$ 生 $^{2}$} & \multicolumn{2}{|c|}{$10 \pi \mathrm{m}^{3} / 4$} & \multicolumn{2}{|c|}{$20 \mathrm{sm}^{3} /$ 年 $^{2}$} \\
\hline & & 千四/年 & $\mathrm{H} / \mathrm{m}^{3}$ & $4 \mathrm{~A} /$ 年 & $\mathrm{m} / \mathrm{m}^{3}$ & $414 / 4$ & $\mathrm{H} / \mathrm{m}^{3}$ \\
\hline & 原料代 & 30,000 & 1,000 & 100,000 & $\angle, 000$ & 200,000 & 1.000 \\
\hline & 㷋料狌 & 97.738 & 1.955 & 195.476 & 1.955 & 390,952 & 1.955 \\
\hline & 犺脂類 & 398 & 8 & 596 & 6 & 894 & 4 \\
\hline & 珪 秒 & 16,000 & 320 & 32,000 & 320 & 64,000 & 320 \\
\hline & $\mathrm{Ca}(\mathrm{OH})_{2}$ & 3.712 & 24 & 2,424 & 74 & 14.848 & 34 \\
\hline & 之a他 & 3.500 & 20 & 6,500 & 65 & 12,250 & 61 \\
\hline & 小計 & 171,348 & 3.427 & 341.996 & 3.420 & 682.944 & 3.415 \\
\hline & 作蒙員 & 78000 & 1.560 & 114,000 & 1.140 & 120,000 & 600 \\
\hline & 事檠員 & 6.000 & 120 & 8,000 & 80 & 10,000 & so \\
\hline & 係 亘 & 20.000 & 400 & 24,000 & 240 & 24.000 & 120 \\
\hline & 竟任者 & 6,000 & 120 & 6,000 & 60 & 6.000 & 30 \\
\hline & 小訫 & 110,000 & 2.200 & 152,000 & 1,520 & 160,000 & 800 \\
\hline & 電力料金 & 30,455 & 609 & 57.064 & 570 & 94,608 & 473 \\
\hline & 用水费 & 4.180 & 84 & 4.940 & 49 & 5,700 & 29 \\
\hline & 修理垬 & 8,290 & 166 & 11,371 & 114 & 16.901 & 85 \\
\hline & 㑽却费 & 49.740 & 295 & $\quad 68.226$ & 682 & 101.406 & 507 \\
\hline & 钤棈金利 & 66,320 & 1.326 & 90.968 & 910 & 135.208 & 676 \\
\hline & 造転金利 & 6.796 & 136 & 11.170 & 112 & 18,357 & 92 \\
\hline & 国定资座税 & 1.737 & 155 & 10.613 & 106 & 15374 & 79 \\
\hline & 兰の地 & 5,000 & 100 & 7,500 & $7^{5}$ & 11.250 & 56 \\
\hline & 㖕 & 178,518 & $3,5>0$ & 261.852 & 2,619 & 329.204 & 1.996 \\
\hline & 計 & 459,866 & 9.197 & 255,848 & 2,558 & $1,242,14^{8}$ & 6.211 \\
\hline
\end{tabular}

主であること等を考えると, 北海道を立地条件とする人工軽量骨 材の生産は，現時点においては経済的に甚だ困難と考えられる。

\section{6. を め}

選炭廃棄物の有効処理策の 1 つとして, 人工軽量骨材化の試験 と，その製造コストの試算を行なつた。技術的には製造可能と考 えられるが, コスト面では炭鉱の立地が人工軽量骨材の主需要地 である関東・関西に遠いため, 現時点では経済的に困難と考えら れる。

[新技術紹介]

（8）石灰・セメント系グラウトについて

小野田セメント（株）中央研究所主任研究員 下 田 正 雄 


\section{1. 緒言}

グラウトは, シールド工法, 推進工法, 地盤改良, 止水・防水 工事などで都市土木, 山岳トンネル，海底開発などあらゆる分野 で広く使用され，ますますその重要性を高めている。

石灰・セメント系グラウトは，古くから使用されているが，近 年, 無機質であり無公害であることが見直されていることと，グ ラウトとして要求されている特性を満足するように改良されたも のが開発されていることにより，その適用範团を拡げつつある。

本報では，石灰・セメント系グラウトの開発ポイント，注入工 法, 適用範囲, 実施例として, 都営地下鉄 10 号線 パイロットシ ールドにおける裏込め注入工などについて概説した。

\section{2. グ ラウト}

\section{$2 \cdot 1$ グラウトとして要求される諸特性}

グラウトとして要求される特性としては, (1)現場の状況に応じ てゲルタイムの調節が可能であること，(2)注入後のブリージング が少ないこと，(3)所定の強度発現があること，(4)硬化後，膨張性 を有すること，(5)透水性，吸水性が少ないこと，(6)土王を受けた とき移動しないこと，(7)圧密脱水がないこと，(8)無公害であるこ となどが挙げられる。これらの要求特性を満足できるグラウトが, 最も優れたものといえる。無機質の材料で，これらの特性を満足 させるためには，セメント化学的見地からの材料開発が必要であ る。

\section{$2 \cdot 2$ 生石灰, セメン卜類が保有しているグラウトとしての 諸特性}

$2 \cdot 2 \cdot 1$ 生石灰の吸水量, 膨張, 化学反応性生石灰は, 水と反応して消石灰を生成する。この化学反応は, 式(1)で与えら

\begin{tabular}{|c|c|c|c|}
\hline 化合物 项 目 & $\begin{array}{l}\text { セメント中の } \\
\text { 含有量 }(\%)\end{array}$ & 水和 反応生成 物 & $\begin{array}{l}\text { 化合物に対 } \\
\text { する理諭水量 }\end{array}$ \\
\hline $\begin{array}{l}3 \mathrm{CaO} \cdot \mathrm{SiO}_{2} \\
2 \mathrm{CaO} \cdot \mathrm{SiO}_{2} \\
3 \mathrm{CaO} \cdot \mathrm{Al}_{2} \mathrm{O}_{3} \\
4 \mathrm{CaO} \cdot \mathrm{Al}_{2} \mathrm{O}_{3} \cdot \mathrm{Fe}_{2} \mathrm{O}_{3} \\
\mathrm{CaSO} .\end{array}$ & $\begin{array}{r}41.6 \\
34.3 \\
6.7 \\
9.5 \\
4.0\end{array}$ & $\begin{array}{l}2 \mathrm{CaO} \cdot \mathrm{SiO}_{2} \cdot 5 \mathrm{H}_{2} \mathrm{O}+\mathrm{Ca}(\mathrm{OH})_{2} \\
3 \mathrm{CaO} \cdot 2 \mathrm{SiO}_{2} \cdot \mathrm{H}_{2} \mathrm{O}+\mathrm{Ca}(\mathrm{OH})_{2} \\
3 \mathrm{CaO} \cdot \mathrm{Al}_{2} \mathrm{O}_{3} \cdot 6 \mathrm{H}_{2} \mathrm{O} \\
3 \mathrm{CaO} \cdot \mathrm{Al}_{2} \mathrm{O}_{3} \cdot 6 \mathrm{H}_{2} \mathrm{O}+2 \mathrm{CaO} \cdot \mathrm{Fe}_{2} \mathrm{O}_{3} \cdot 5 \mathrm{H}_{2} \mathrm{O} \\
3 \mathrm{CaO} \cdot \mathrm{Al}_{2} \mathrm{O}_{3} \cdot 3 \mathrm{CaSO} \mathrm{Ca}_{4} \cdot 30 \sim 32 \mathrm{H}_{2} \mathrm{O}\end{array}$ & $\begin{array}{r}47.5 \\
10.5 \\
40.0 \\
37.1 \\
137.0\end{array}$ \\
\hline 合 & 96.1 & - & 35.0 \\
\hline
\end{tabular}

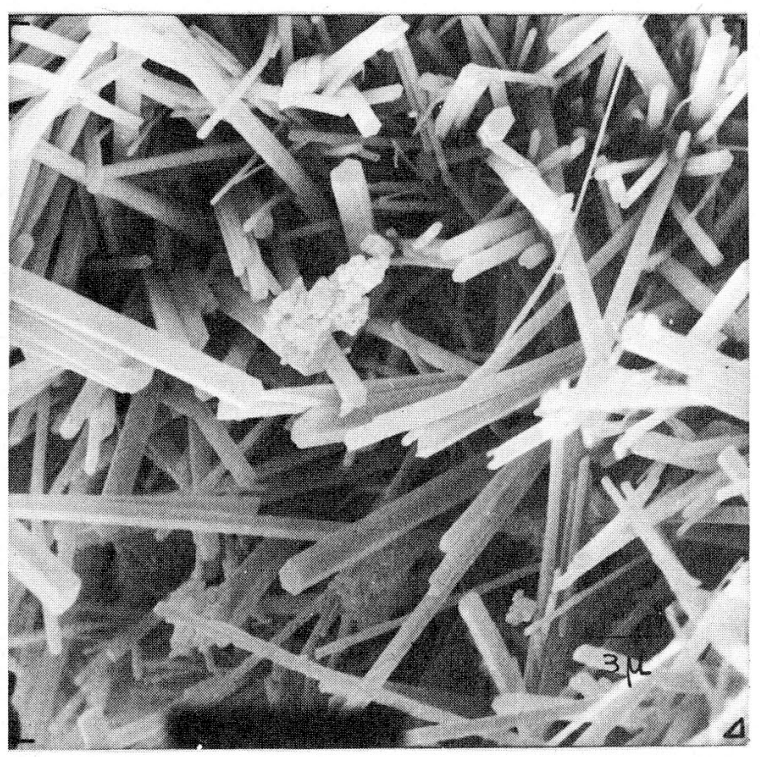

第 1 図エトリンガイトの走查電子顕微鏡写真
れる。すなわち, 生石灰は, その重量の 32 \% の水を消化吸水し $\mathrm{CaO}+\mathrm{H}_{2} \mathrm{O} \rightarrow \mathrm{Ca}(\mathrm{OH})_{2}+15.6 \mathrm{kcal} / \mathrm{mol} \cdots \cdots \cdots \cdots(1)$

て消石灰を生成する。生成した消石灰は, 絶対乾燥状態 $(\mathrm{pF}=7$, 水頭 $10^{7} \mathrm{~cm}$ ) にあり, 生石灰の $45 \sim 75 \%$ の水を吸着する。さら に式(1)江発熱反応であり, 蒸発によつて生石灰の 45 \% の水を脱 水することができる。したがつて，生石灰の消化吸水，吸着およ び蒸発作用により，生石灰重量の $1.22 \sim 1.42$ 倍の水を吸水するこ とになる。

生石灰と消石灰の真体積の関係は，式(2)で与えられる。

$1.98 V_{\mathrm{CaO}}=V_{\mathrm{Ca}}(\mathrm{OH})_{2}$

ここに $V_{\mathrm{CaO}}:$ 生石灰の真体積

$V_{\mathrm{Ca}}(\mathrm{OH})_{2}$ : 消石灰の真体積

すなわち, 生石灰が水和して消石灰に移行すると体積は, 約 2 倍に膨張する。

生成した消石灰は，へドロ，粘土，フライアッシュ，高炬水涬， シラスなどのポゾラン反応により，アルミン酸カルシウム水和物， ケイ酸カルシウム水和物などを生成し硬化する特長を有している。

$2 \cdot 2 \cdot 2$ セメント水和生成物による水の固定亡水和速度 普通ポルトランドセメントの理論水和量は， $28 \sim 36 \%$ である。 第 1 表にみるように，水和生成物中のエトリンガイト（ $3 \mathrm{CaO}$. $\mathrm{Al}_{2} \mathrm{O}_{3} \cdot 3 \mathrm{CaSO}_{4} \cdot 32 \mathrm{H}_{2} \mathrm{O}$ )（第 1 図）は, セメント類の水和生成 物中, 最も水の固定量が大きく, 結晶構造中に 32 分子もの水を 結晶として固定することができ，その理論我着は $13.7 \%$ である。 その他, アルミン酸一硫酸カルシウム $\left(3 \mathrm{CaO} \cdot \mathrm{Al}_{2} \mathrm{O}_{3} \cdot \mathrm{CaSO}_{4}\right.$ $\left.12 \mathrm{H}_{2} \mathrm{O}\right), ア ル ミ ン$ 酸カルシウム水和物 $\left(4 \mathrm{CaO} \cdot \mathrm{Al}_{2} \mathrm{O}_{3} \cdot 13 \mathrm{H}_{2} \mathrm{O}\right)$ （第 2 図）なども結晶水として水を固定する能力の比較的大きい 水和生成物といえる。また，これらの水和物は，ケイ酸カルシウ 么水和物に比べ, 水和速度が速いことも特徵として挙げることが できる。

$2 \cdot 2 \cdot 3$ 生石灰, セメント類が保有している諸特性とグ ラウト特性生石灰, あるいはセメント水和物中のエトリ ンガイト，アルミン酸カルシウムなどは，水の固定量が多く， 水和反応速度が早いことを特徵としている。また，生石灰は 膨張特性をも有している。したがつて，生石灰，あるいはこ れらのセメント水和物が多く生成するようなセメント類を調 製することがグラウトとして優れている。すなわち，このよ

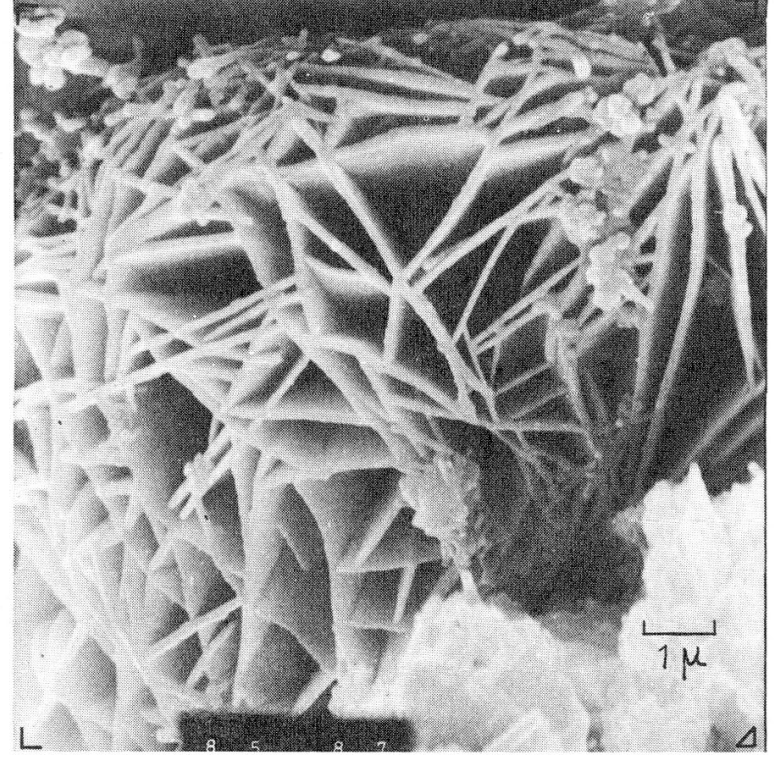

第 2 図 アルミン酸カルシウム水和物の走査電子顕微鏡写真

日本鉱業会誌/941088（'78-10） $719<23\rangle$ 
グラウト方式

グラウト材料の混合過程による種類

(1) 1 ショット方式（1 液 1 工程方式）

(2) 1.5 ショット方式(2液1工程方式): Y 字管による

(3) 2.0 ショット方式(2液1工程方式)

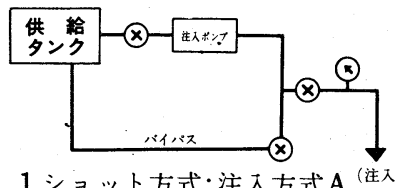

1 ショット方式:注入方式 $\mathrm{A}^{\text {(注入) }}$

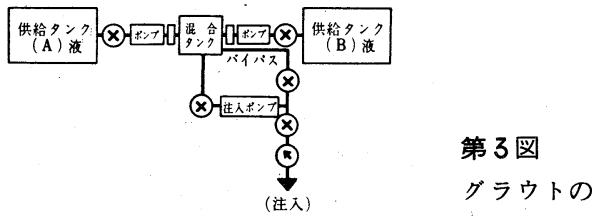

1.5 ショット方式: 注入方式B

注入方式

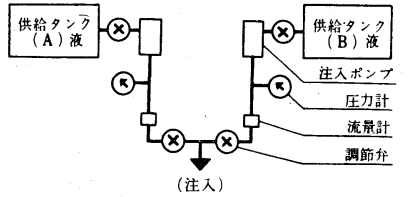

2 ショット方式: 注入方式C

うな特性を備えた材料は, グラウトとして一般的に要求されてい るブリージングの少ない, ゲルタイムの調節可能な膨張性を有す るなどの特性を具備しているといえる。

\section{3. グラウトの注入工法}

グラウトの注入工法は, 注入王力からの分類と注入方式による 分類とが一般に行なわれている。注入王力からの分類としては， $0.5 \sim 70 \mathrm{~kg} / \mathrm{cm}^{2}$ の圧力で, 地盤注入, 空洞填充する一般注入工 法と $150 \sim 700 \mathrm{~kg} / \mathrm{cm}^{2}$ の圧力で地盤注入する高压注入工法とがあ る。また, 注入方式からの分類としては, 第 3 図に示すように 1 ショット方式（1 液を 1 工程で注入する方式），1.5ショット方式 （ 2 液を 1 工程で注入する方式）掠よび 2.0 ショット方式（ 2 液を 1 液づつ 2 工程で注入する方式 ) である。

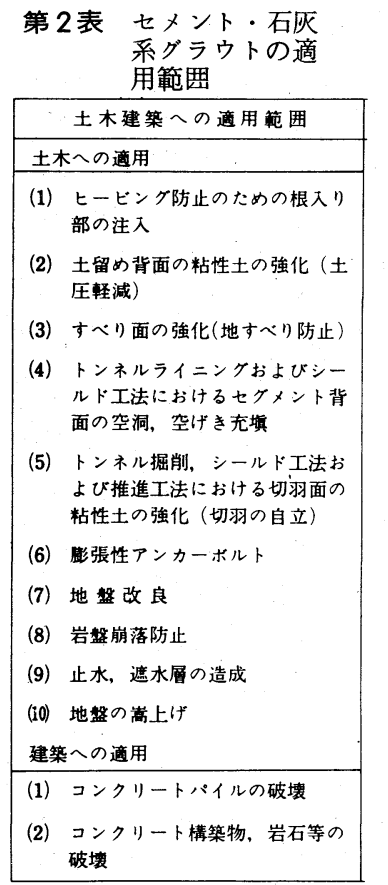

\section{第 4 表 $1 \mathrm{~m}^{3}$ 当りの配合}

\begin{tabular}{|c|l|c|}
\hline ケミコグラウト & 土 量 & 水 \\
\hline $500(\mathrm{~kg}))$ & $750(\mathrm{~kg})$ & $450(\ell)$ \\
\hline
\end{tabular}

第 4 図

生石灰グラウト の硬化モデル

\section{4. 適用 範 囲}

グラウトは, 上下水道, 道路, 鉄道などの建設に伴い止水, 地 盤改良，空洞充填などを目的として使用される。その適用範囲は 第 2 表の通りであるが, 空洞充媜用グラウトとしては, シールド 工法における裏込め充填の他に, 廃坑道, 廃埋設管の空洞, 地盤 沈下のために既設の工場や地下鉄, ビルなどの基礎に生じた空洞, 舗装と路床との間の空洞などの充填, 石油タンクなど構築物の不 等沈下修正のための注入などが考えられる。

5. 都営地下鉄10号線パイロットシールドにおける生石灰 グラウト(ケミコグラウト)による裏込め注入 ${ }^{1)}$

\section{$5 \cdot 1$ 生石灰グラウトの特性}

都営地下鉄 10 号線 パイロットシールドにおおる生石灰グラウ トによる裏込め注入工は, セグメント背面と地山との間にできる 空げきを充填することを目的としたものである。

$5 \cdot 1 \cdot 1$ 注入硬化時間 圱石灰グラウトを地盤に注入して 硬化するまでの時間は, 施工現場の条件に応じて自由に調節する ことができる。また, 水生石灰比は, $0.7 \sim 1.3$ の範囲が適当であ り，非常に流動性に富み充填が容易である。

$5 \cdot 1 \cdot 2$ 硬化 硬化特性のモデルは, 第 4 図に示す通りで ある。すなわち, 注水直後に 1 次発熱があり，一度温度降下があ つて後に, 再び温度上昇とともにゲル化現象が起こり続いて水和 による 2 次発熱を生ずることを特長としている。発熱温度は, 水 和抑制時間が長い程，低温度に調整することができる。注入工に おいては, 粘性より注入, ゲル化および硬化膨張の 3 領域に分け られる。

$5 \cdot 1 \cdot 3$ 強度 硬化後の強度は, 硬化直後より所定の硬度を 発現する。また,現場の拘束条件，混合材などにより異なつた強度 発現をする。その範囲は $2 \sim 200 \mathrm{~kg} / \mathrm{cm}^{2}$ である。

$5 \cdot 1 \cdot 4$ 膨張 硬化後の膨張量は, 施工現場の拘束条件に より異なるが, 必要に応じた膨張量が期待できる。最大膨張量は, 生石灰真体積の 2 倍量であり，軟弱地盤中ではその值を記録する ことが多い。

第 5表 注入ケミュグラウトの特性値

\begin{tabular}{|c|c|c|c|c|c|}
\hline $\begin{array}{l}\text { 含 水 比 } \\
\text { W( }(\%))^{2}\end{array}$ & $\begin{array}{c}7 \text { 只值 } \\
(\text { 秒) }\end{array}$ & $\begin{array}{l}\text { 単位体皘重量 } \\
\gamma_{\mathrm{t}}\left(\mathrm{g} / \mathrm{cm}^{\prime}\right)\end{array}$ & 水 & 比 & $\begin{array}{c}\text { 強 } \\
\text { 28度 } \\
\text { day }\left(\mathrm{kg} / \mathrm{cm}^{\prime}\right.\end{array}$ \\
\hline 12.1 & 26.4 & 1.807 & 0 . & & 28.72 \\
\hline
\end{tabular}

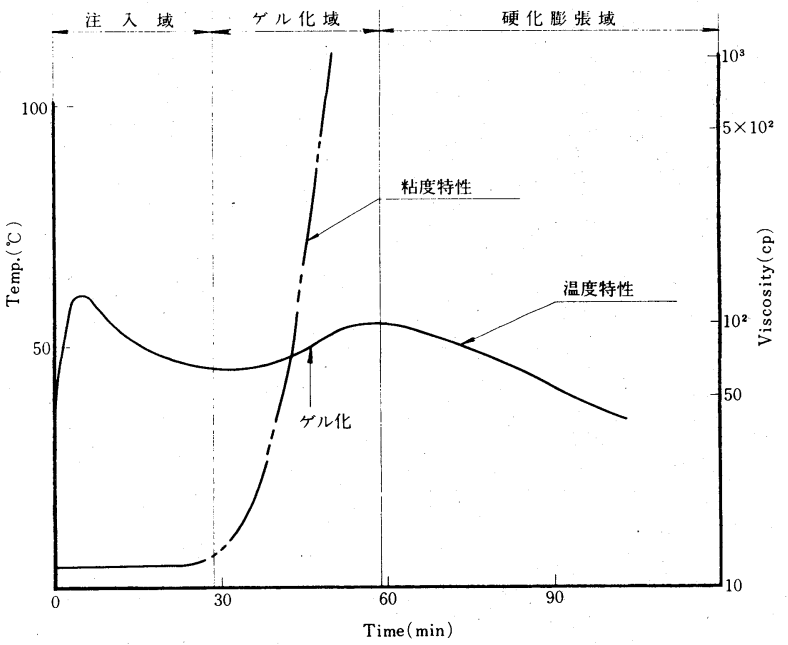


$5 \cdot 1 \cdot 5$ その他 硬化体の圧密脱水がない。ブリージング がない。土压を受けたとき崩壊, 移動がない。透水性, 吸水性が 少ない。などの特性を有している。

生石灰グラウト単独注入でなく, 施工現場の土, 火山灰土, 砂, 砂利, ベントナイト, 鉱涬, フライアッシュ, 硫酸塩, アルカリ およびその塩, セメント類, 発泡剤, 界面活性剤などを混入する ことにより, 品質, 強度, 経済性などを高めることができる。

$5 \cdot 2$ シールドエ法における裹込め注入

シールド工法における裏込めは, 組立てられたセグメントと地 山との間にできる空げきを裏込め材で充填するが, これは地表面 の沈下防止, セグメントに作用する土压の均等化, セグメントの すき間からの漏水, 漏気の防止などの目的を持つている。従来, 裏込め材としては，モルタルにベントナイト，フライアッシュな どを加え流動性をよくして使用されているが，この種のものは， ゲルタイムの調節が困難であつたり, 硬化後に収縮するため地盤 沈下などの原因となり，裏込め材としては十分とはいえない。

生石灰グラウトをこの用途に適用すると, 注入完了後に適度の 強度発現, 体積膨張などの特性を発揮するため, 硬化後に空げき が生ずることがなく，モルタル注入の場合に行なう2 次注入の必 要がない。また，地山のルーズな土粒子を压密することができる。

$5 \cdot 3$ パイロットシールドエ法における裏込め材の要求特性 パイロットシールド工法に扔ける裏込め材の要求特性として, 東京都は, 粘性がマーシュのフローコーンで $26 \mathrm{sec}$ 以上であるこ と。生石灰グラウトの発熱温度が $50^{\circ} \mathrm{C}$ 以下であること。発現強度 が地山強度の 2 倍以上であることなど挙げている。

$5 \cdot 4$ パイロットシールドエ法に注入した生石灰グラウトの 特性

東京都の示した裏込め材の特性を満たすものとして, 生石灰グ ラウトの配合などを第 3 表, 第 4 表および第 5 表に示すように設 定した。基本配合を第 3 表, $1 \mathrm{~m}^{3}$ 当りの配合を第 4 表拉よび特 性値を第 5 表に示した。

\section{$5 \cdot 5$ 施工 1 年後の掘起こし結果}

$5 \cdot 5 \cdot 1$ 状態観察 生石灰グラウトの充媜状況は, 両側壁 部, アーチ部において広範囲に密充填されていることが磼認でき た。また，セグメントとの接着性は良好であり，従来のモルタル による喠込めに比較して膨張していることが観察された。

$5 \cdot 5 \cdot 2$ 生石灰グラウト硬化体の土質工学特性 硬化体を $\phi 50 \mathrm{~mm} \sim 60 \mathrm{~mm}, \mathrm{~L} 100 \mathrm{~mm} \sim 120 \mathrm{~mm}$ に成形し, 土質工学特性を 測定した。結果を第 6 表に示した。結果によるとおのおの平均値 で, 単位体積重量 $\gamma_{t-c}=1.75 \mathrm{t} / \mathrm{m}^{3}$, 一軸圧縮強さ $q_{u-c}=7.90$
第 6表 ケミコグラウト硬化体一年材令に おける土質工学特性

\begin{tabular}{|c|c|c|c|c|c|c|}
\hline 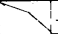 & 単位体積重量 & 一軸圧縮強度 & 七スミ & 含水比 & \multirow{2}{*}{ 備 } & \multirow{2}{*}{ 考 } \\
\hline 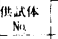 & $\gamma_{t}\left(t / m^{3}\right)$ & $\mathrm{q}_{\psi}\left(\mathrm{kg} / \mathrm{cm}^{2}\right)$ & $\varepsilon(\%)$ & $\mathrm{w}(\%)$ & & \\
\hline 1 & 1.77 & 7. 37 & 1. 52 & 35.7 & \multirow{10}{*}{$\begin{array}{l}\qquad \\
\text { No. } 1 \text { No } 10.10 \\
\text { のケミコグラ } \\
\text { ウト供試体 } \\
\phi: \\
50 \mathrm{~mm} \sim 60 \mathrm{~mm} \\
\text { Lo: } \\
100 \mathrm{~mm} \sim 120 \mathrm{~mm}\end{array}$} & 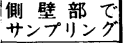 \\
\hline 2 & 1. 71 & 6.00 & 1. 15 & 35.4 & & $"$ \\
\hline 3 & 1.68 & 7.70 & 1. 16 & 33.7 & & $"$ \\
\hline 4 & 1.62 & 7. 26 & 1. 28 & 30.9 & & $"$ \\
\hline 5 & 1. 81 & 6.81 & 1. 10 & 34.6 & & $"$ \\
\hline 6 . & 1. 68 & 7. 51 . & 1. 38 & 33.9 & & $"$ \\
\hline 7 & 1. 79 & 7. 62 & 1. 75 & 34.8 & & " \\
\hline 8 & 1. 77 & 9. 22 & 1.63 & 56.1 & & $\begin{array}{l}\text { 天端部分で } \\
\text { サンブリンク }\end{array}$ \\
\hline 9 & 1. 96 & 13.01 & 1. 51 & 54.4 & & $"$ \\
\hline 10 & 1. 74 & 6.48 & 1. 55 & 49.1 & & $"$ \\
\hline 平均 & $1: 75$ & 7. 90 & & 39.9 & & \\
\hline 地山 & 1. 59 & 4.04 & 1. 59 & 55.3 & 固䊅シルト & $\begin{array}{l}\text { 現場にてサ } \\
\text { ンプリグ }\end{array}$ \\
\hline
\end{tabular}

$\mathrm{kg} / \mathrm{cm}^{3}$, 含水比 $W_{c}=39.9 \%$, ヒズミ $\varepsilon_{c}=1.40 \%$ である。比較の ため地山土を採取し, 土質工学特性を測定したところ, 単位体積 重量 $\gamma_{t-s}=1.59 \mathrm{t} / \mathrm{m}^{3}$, 一軸圧縮強さ $q_{u-s}=4.04 \mathrm{~kg} / \mathrm{cm}^{2}$, 含水 比 $W_{s}=55.3 \%$, 七ズミ $\varepsilon_{s}=1.59 \%$ の固結シルトと称するよく締 まつた岩泥である。

本注入工は, 生石灰グラウトの発熱現象が認められるものの順 調に施工できた。硬化体の一軸圧縮強さは, 地山強さの 2 倍を示 し, 十分満足するものであつた。また, 硬化体の膨張特性より, 地山のルーズな土粒子を正密することもできた。

\section{6. むす}

石灰・セメント系グラウトが, 従来のセメントあるいはモルタ ルグラウトよりも優れたものとして開発されていることを述べた。 それに伴つて, 土木建築工事における適用範用が拡大されている。 また, 注入工法も開発されるに至つている。

実施工に当つては, 現場のグラウトに対する要求特性を把握し た上で, それに適したグラウトの選定, 調製を行なうことが重要 である。

近年, 極徵細粒子からなるグラウトの開発が望まれている。近 い将来, 新しいグラウトおよび工法が誕生し, 土木工事の一翼を 担うことを期待している。

$$
\text { 文献 }
$$

1）下田正雄・岡田能彦・西尾経 - 金德一：小野田研究報告 1975,27 [94], $136 \sim 143$.

[新技術紹介]

(9) SALA-HGMS 高勾配磁気分離装置と石炭の脱硫, 脱灰への適用について

$$
\text { サラ・ファー・イースト(株) 七 里直 }
$$

\section{1. はじめに}

石炭中に存在する硫黄含有鉱物や灰分構成鉱物等を除去する方 法として現在は，粉砕，ふるい分け，重選，浮選等が，工業的に 一般化しているが，これらの釯物のほとんどが常磁性で，石炭は 反磁性であるところから，この磁性の相反する性質を利用して磁 気分離を行なう試みが過去 10 数年来, 主としてアメリカで取上げ られ, それに関する研究論文は, 質, 量ともどもぼう大なものが
発表されている。

石炭中の硫黄には, 有機物と無機物とがあり, 両者の存在比率 は, 産出地によつて大幅に変つている。わが国の三池炭の例をと ると, 全硫黄含有率が $1 \sim 5 \%$ そ, その中の $70 \sim 80 \%$ は有機物 で，これは石炭と同様に反磁性で，石炭から磁気分離できないし， また浮選によつても分離できない。このような事情からわが国で は, 石炭燃焼前より, 燃焼後に硫黄を取除く方式, すなわち, 排 煙脱硫技術の開発が進み，磁気分離はかえりみられなかつた。し 